\section{Post-fire effects and short-term regeneration dynamics following high- severity crown fires in a Mediterranean forest}

\author{
Raffaella Marzano (1), Emanuele Lingua ${ }^{(2)}$, Matteo Garbarino (1)
}

Resilience against fire disturbance of Mediterranean vegetation has been frequently described. However, due to climatic change and abandonment of local land use practices, the fire regime is changing, probably leading to higher intensities and frequencies of disturbance events. The forthcoming scenario calls for a full understanding of post-disturbance tree recruitment processes, structural resilience and possible consequences on the overall forest biodiversity. In particular, knowledge on severe crown fires' effects on forest stand structural attributes needs to be further explored. In this work, we describe and quantify fire impact and short-term response of a Mediterranean forest affected by high severity crown fires, focusing on the compositional and structural diversity of living and dead trees, spatial pattern of fire-induced mortality, recovery dynamics of tree species. The analysis, based on a synchronic approach, was carried out within four burned and two not burned fully stem-mapped research plots located in NW Italy, belonging to two forest categories differing for their main tree restoration strategies. Distance-dependent and distance-independent indices were applied to assess structural diversity dynamics over time since fire occurrence. Within the analyzed forests fire was found to affect mostly forest structure rather than its composition. Number of snags largely increases immediately after the fire, but it levels off due to their fall dynamics. Regeneration strategies and fire severity influenced species abundance and consequently diversity patterns. Stem diameter and height diversity were modified as well, with a strong increase in the first post-fire year and a sharp reduction six years after the disturbance. Fire determined also a higher heterogeneity in crown cover and vertical structure. Spatial patterns of surviving trees and snags were greatly affected by fire, producing an increase in aggregation and segregation mechanisms. Autosuccessional processes are supposed to preserve current forest structure and composition, but the ecosystem selfrestoring capability should be analyzed in the light of the possible changes in fire regime.

Keywords: Structural diversity, Snag dynamics, Pinus pinaster, Regeneration strategies, Fire severity

\section{Introduction}

Fire is recognized as the most important natural disturbance in Mediterranean ecosystems (Trabaud 1994, Whelan 1995). In the Mediterranean basin, given the long historical human impact on ecosystems, the incidence of fire has always been particularly high (Le Houérou 1987, Trabaud 1987a). In addition to natural causes of ignition, burning was one of the management tools commonly used by man (Naveh 1975, Lloret \& Marí 2001). Fire thus acted as a fundamental factor on ecosystem functioning and as a major ecological driver of vegetation changes (Attiwill 1994, Moreno \& Oechel 1994, Lavorel et al. 1998), by modeling landscapes (Gillson 2009) and contributing to maintain habitat heterogeneity and biological diversity
(Moreira et al. 2001, Blondel et al. 2010).

Even though fires have been a major factor in Mediterranean ecosystems for millennia, the general trend in number of fires and area burned in European Mediterranean areas has dramatically increased during the last decades, principally due to land-use and climatic changes (Piñol et al. 1998, Lloret \& Marí 2001, Mouillot et al. 2002, González \& Pukkala 2007, Pausas \& Fernández-Muñoz 2012). According to the predicted climate change scenarios for the Mediterranean region, further increases in wildfire frequency and burned areas are expected (Carvalho et al. 2008, Good et al. 2008).

Although Mediterranean vegetation is able to cope with fire (Trabaud 1987a, Pausas 1999a), alterations in the fire regime (in
(1) Department AGROSELVITER, University of Torino, v. L. Da Vinci 44, I10095 Grugliasco (TO - Italy); (2) Department TESAF, University of Padova, v.le dell'Università 16, I-35020 Legnaro (PD - Italy)

@ Raffaella Marzano (raffaella.marzano@unito.it)

Received: Oct 23, 2011 - Accepted: Apr 05, 2012

Citation: Marzano R, Lingua E, Garbarino M, 2012. Post-fire effects and short-term regeneration dynamics following highseverity crown fires in a Mediterranean forest. iForest 5: 93-100 [online 2012-05-30] URL: http://www.sisef.it/iforest/contents/? id=ifor0612-005

terms for instance of higher fire recurrence or incidence of large events) can generate important consequences for Mediterranean ecosystems (Zedler et al. 1983, Vázquez \& Moreno 2001, Lloret et al. 2003) and their plant diversity. Given the very strong effect of fire on vegetation, plant distribution and ecosystem function could likely be more heavily affected by the ongoing modifications in fire regime consequent to global changes than by the direct effect of climate changes (Pausas \& Fernández-Muñoz 2012). Moreover, the combined impact of these fire regime changes and enlarged environmental limitations for post-fire tree recruitment could deeply affect the species composition of Mediterranean forests (Peñuelas \& Filella 2001, Peñuelas et al. 2002, Lloret et al. 2004, 2009).

It is well documented that Mediterranean ecosystems recover readily after fire through an autosuccessional process (Hanes 1971, Trabaud 1994) based on efficient regeneration strategies. Post-fire recovery is usually realized by direct regeneration, i.e., the fast recovery of a plant community made up by the same species pool that existed before the disturbance (Rodrigo et al. 2004). Two main plant regeneration strategies conferring resilience to Mediterranean ecosystems are the capacity to resprout after fire (resprouter species), and the stimulation of the recruitment by fire (seeder species - Bond \& van Wilgen 1996, Verdú et al. 2007). In several fire-prone communities varying proportions of woody sprouters and seeders are included (Hodgkinson 1998, Lloret \& Vilà 2003). Fire regime may influence the relative abundance of sprouters and seeders (Lloret et al. 2005). Since significant changes in disturbance regimes are predicted by global change scenarios, more attention must be paid to the ecosystems' ability to recover 
(Dury et al. 2011). Among the main research needs for Mediterranean forests, key topics are resilience to disturbance in genera (Lavorel 1999, Scarascia-Mugnozza et al 2000) and post-fire recruitment processes in particular (Vega et al. 2010).

The main aim of this work was to describe and quantify short-term vegetation response after high-severity crown fires in a Mediterranean forest with stands featuring a different composition of seeder and resprouter woody species in the tree layer. Recovery processes were investigated to disclose differences in resilience mechanisms among species with different restoration strategies. Specific research goals were the assessment of: (a) compositional and structural diversity of living and dead trees; (b) spatial pattern of fire-induced mortality; (c) recovery dynamics of tree species.

\section{Materials and methods}

\section{Study site}

The study was carried out in the province of Savona, Central Liguria, NW Italy (lat $44^{\circ}$ $12^{\prime}-44^{\circ} 19^{\prime} \mathrm{N}$, long $\left.8^{\circ} 22^{\prime}-8^{\circ} 28^{\prime} \mathrm{E}\right)$. The geologic bedrock is quite heterogeneous and is mainly represented by Cenozoic and Mesozoic igneous and metamorphic rocks. The climate is typical Mediterranean, with mild and moderately moist winters and warm and dry summers, characterized by a significant summer drought. Along with a few remaining monospecific Pinus pinaster Aiton stands, the majority of forests are mixed stands, with both conifer (mainly $P$. pinaster) and broadleaved species (including mainly oaks - Quercus pubescens Willd., Quercus ilex L. -, as well as Castanea sativa Miller, Fraxinus ornus L., and other woody species like Erica arborea L., Arbutus unedo L.) or with a predominance of broadleaves. The fire regime, as throughout Liguria Region, is characterized by frequent and severe wildfires, spread all over the year, but mostly concentrated during summer (Mar- zano 2006).

Two high severity crown fire events, located in close proximity $(<10 \mathrm{~km})$, were selected for a case study. The first wildfire occurred in August 1998 and burned 146 ha, while the second occurred in August 2003 and burned 235 ha. Burned areas within the fire perimeters were differentiated according to the percentage of seeder and sprouter species in the overstory, identifying two main forest categories: the mixed-broadleaved forest category (henceforth: MB) characterized by the predominance of sprouters, and the broadleaved-coniferous forest category (BC) made up by both sprouters and obligate seeders.

\section{Sampling}

We established one intensive sampling plot for each forest category inside the fire perimeters (BC_03; BC_98; MB_03; MB_98) and another one for each forest category in the surrounding unburned area as control plot (BC_nb; MB nb). The latter were not burned by high intensity fires since 20 years at least.

Each plot $(50 \times 50 \mathrm{~m})$ has one side parallel to the maximum slope. Within each plot all living trees and shrubs (stems with $\mathrm{dbh} \geq 3$ $\mathrm{cm}$ ), snags (standing dead trees with $\mathrm{dbh} \geq 3$ $\mathrm{cm}$ and height $>1 \mathrm{~m}$ ), logs (downed dead trees or part of, with the biggest size diameter $\geq 10 \mathrm{~cm}$ ), and stumps (surface diameter $\geq$ $10 \mathrm{~cm}$ and height $\leq 1 \mathrm{~m}$ ) were identified, labeled with numbered plastic tags and mapped with a total survey station (Geotronics - Geodimeter 400). Sampling activities were carried out in summer 2004.

For every living stem, we recorded species, diameter at breast height (dbh), total height, height of lowest living branches (upslope and downslope), four radii of the crown projection on the ground. For each snag, log or stump inside the plot, the species based on distinguishing traits not modified by fire, the diameter (dbh for snags, diameter on both ends for logs, diameter at the root collar for

Tab. 1 - Stand characteristics of the six investigated plots. (BC nb): not burned broadleaved-coniferous forest stand; (BC 03): broadleaved-coniferous forest stand burned in 2003; (BC_98): broadleaved-coniferous forest stand burned in 1998; (MB_nb): not burned mixed-broadleaved forest stand; (MB_03): mixed-broadleaved forest stand burned in 2003; (MB_98): mixed-broadleaved forest stand burned in 1998.

\begin{tabular}{|c|c|c|c|c|c|c|}
\hline Plots & BC_nb & BC_03 & BC_98 & MB_nb & MB_03 & MB_98 \\
\hline Mean elevation (m a.s.1.) & 277 & 231 & 277 & 236 & 225 & 170 \\
\hline Aspect & $\mathrm{N}-\mathrm{E}$ & $\mathrm{N}-\mathrm{E}$ & $\mathrm{N}-\mathrm{E}$ & S-E & S-W & $\mathrm{N}-\mathrm{W}$ \\
\hline Slope (degrees) & 22 & 28 & 22 & 29 & 19 & 17 \\
\hline Living stem density (stems ha ${ }^{-1}$ ) & 2310 & 182 & 929 & 3787 & 394 & 994 \\
\hline Living stem basal area $\left(\mathrm{m}^{2} \mathrm{ha}^{-1}\right)$ & 15.8 & 5.8 & 2.9 & 16.8 & 7.9 & 4.9 \\
\hline Snag density $\left(\right.$ stems $\left.\mathrm{ha}^{-1}\right)$ & 345 & 2716 & 1421 & 425 & 2643 & 348 \\
\hline Snag basal area $\left(\mathrm{m}^{2} \mathrm{ha}^{-1}\right)$ & 4.3 & 23.8 & 10.1 & 2.1 & 19.9 & 1.1 \\
\hline Regeneration density $\left(\mathrm{n} \mathrm{ha}^{-1}\right)$ & 9800 & 11100 & 21900 & 7300 & 11900 & 1600 \\
\hline Regeneration richness (n taxa) & 5 & 6 & 10 & 7 & 10 & 7 \\
\hline
\end{tabular}

stumps) and the total height (snags, stumps) or length $(\operatorname{logs})$ were recorded. The number of post-fire resprouts of tree and shrub species was also recorded. Tree seedlings and saplings were recorded within sixteen square subplots $\left(6.25 \mathrm{~m}^{2}\right)$ randomly established inside each $50 \times 50 \mathrm{~m}$ plot.

\section{Structural diversity}

Structural diversity within plots was assessed applying both distance-independent and distance-dependent measures. For more details on the diversity indices used, see Appendix 1

The Brillouin index $(H B)$ and the Evenness $(E)$ for the Brillouin index (Brillouin 1956, Magurran 2004) were computed to describe the variability in woody species abundance.

Following Kuuluvainen et al. (1998), we used the distribution of tree heights to represent the vertical structure of the forest. The tree height diversity (THD) index was computed for living stems and snags (Kuuluvainen et al. 1996), adopting 2.5-m-deep horizontal layers. We also applied the tree diameter diversity (TDD) index (Rouvinen \& Kuuluvainen 2005) to $5 \mathrm{~cm}$ dbh classes of living and dead stems.

The vertical distribution of canopy cover within the plots was assessed through the Vertical Evenness (VE) index by Neumann \& Starlinger (2001).

To describe the tree spatial pattern within the plots, Point Pattern Analysis (PPA) techniques were applied by means of Ripley's $K$ (Ripley 1977) using the software SPPA 2.0 (Haase 2001). Since the cumulative $K$-function confounds effects at larger distances with effects at shorter distances (Getis \& Franklin 1987), the O-ring functions (Wiegand et al. 1998) were adopted as complementary analyses using the PROGRAMITA software (Wiegand \& Moloney 2004).

To determine the distributions of trees or tree-classes as random, regular or clumped, univariate Ripley's $K(t)$ and $O(r)$ functions were applied. To assess the relationships between classes (i.e., living vs. dead), we examined bivariate spatial interactions using Ripley's $K_{12}(t)$ (Lotwick \& Silverman 1982) and $O_{12}(r)$ functions (Wiegand et al. 1998).

We considered as living the individual stools showing at least one shoot $(\mathrm{dbh} \geq 3$ $\mathrm{cm}$ ) alive. All the analyses were carried out only for classes having more than 20 elements, and starting from $1 \mathrm{~m}$ up to $25 \mathrm{~m}$ applying a $1 \mathrm{~m}$ lag distance, thus not exceeding half of the study area in order to limit the influence of the margin effects (Haase 1995).

Null models were chosen for the different analyses to avoid misinterpretation of the results (Goreaud \& Pélissier 2003). Complete spatial randomness (CSR) was adopted as null model for the univariate analyses. For the living $v s$. dead stems analysis, we chose the null hypothesis of random mortality ap- 

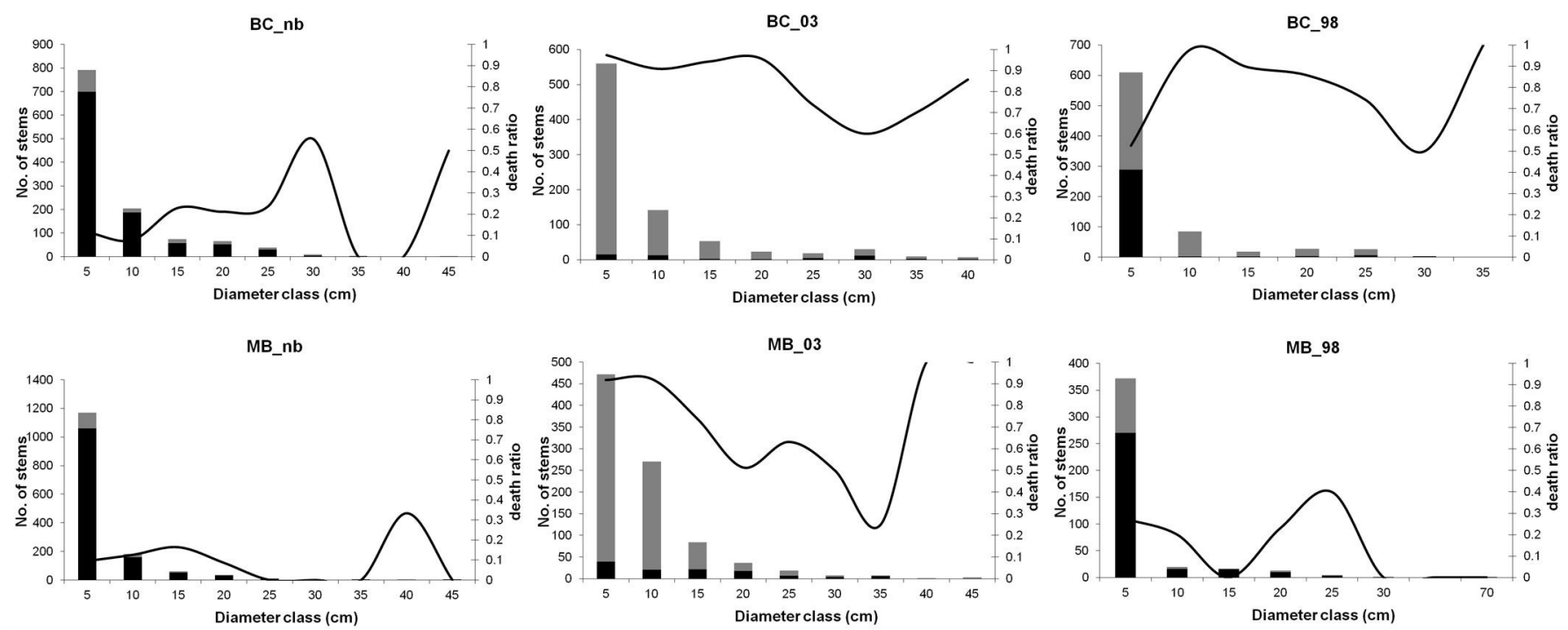

Fig. 1 - Diameter distribution of living stems and snags. Living stems are represented in black, snags in grey. Solid lines correspond to the death ratio, i.e., the proportion between dead and total stems in a given diameter class.

plying the random labeling (Kenkel 1988), since the mortality agents (i.e., wildfires) can only work within the limits set by the distribution of living trees prior to the disturbance events themselves (Aakala et al. 2007).

\section{Results}

A total of 6482 living stems, snags, logs and stumps were recorded, mapped and measured in the tree layer of the 6 investigated plots. Living stem density (Tab. 1)

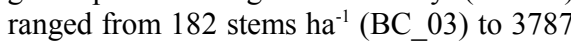
stems ha $^{-1}$ (MB_nb). Snag density ranged from 345 stems $\overline{h a}^{-1}$ (BC nb) to 2716 stems ha $^{-1}$ (BC_03). Basal area of living stems (Tab. 1) ranged from $2.9 \mathrm{~m}^{2} \mathrm{ha}^{-1}$ (BC 98) to $16.8 \mathrm{~m}^{2} \mathrm{ha}^{-1}$ (MB_nb). Concerning snags, the lowest basal area $\left(1.1 \mathrm{~m}^{2} \mathrm{ha}^{-1}\right)$ was also recorded in MB 98, while the maximum value $\left(23.8 \mathrm{~m}^{2} \mathrm{ha}^{-1}\right)$ was found in BC_03.

Comparable values in density of seed germinated individuals were found for unburned plots and those burned in 2003 (Mann-Whitney test; $\mathrm{p}>0.05$ ), whereas a highly significant difference occurred in 1998-burned plots (Mann-Whitney test; $\mathrm{p}<0.001$ )

The size-class distribution of living stems and snags was reverse $J$-shaped for all the six plots (Fig. 1). Larger stems were mostly maritime pine trees, secondarily oaks and chestnut. The major difference between plots is the different contribution of snags and living stems to size classes. Along the postfire chronosequence, the most represented size class was the $5-\mathrm{cm}$ one. In the unburned plots almost $90 \%$ of stems belonging to this size class was made up by living stems, while immediately following the fire events, it included almost exclusively dead stems.

Among the most abundant species in the overstory, Arbutus unedo and Fraxinus ornus showed a high resprouting percentage in both 2003 plots (Tab. 2), while as expected in the two 1998-burned plots the percentage is reduced, with no significant differences in $\mathrm{BC}$ and $\mathrm{MB}\left(\chi^{2}\right.$ test; $\left.\mathrm{p}>0.05\right)$. Erica arborea had a different behavior in the

two plots burned in 2003, with a higher resprouting percentage in BC_03 $\left(\chi^{2}\right.$ test; $\mathrm{p}<0.001)$. In the two 1998-burned plots the resprouting percentages are still high, with no significant differences. Similarly, Castanea sativa showed a higher resprouting per-

Tab. 2 - Number of top-killed stools and resprouting percentage [Re. (\%)] in the four burned plots, for the main resprouting species. (BC_03): broadleaved-coniferous forest stand burned in 2003; (BC 98): broadleaved-coniferous forest stand burned in 1998; (MB_03): mixedbroadleaved forest stand burned in 2003; (MB_98): mixed-broadleaved forest stand burned in 1998.

\begin{tabular}{|c|c|c|c|c|c|c|c|c|}
\hline \multirow{2}{*}{ Species } & \multicolumn{2}{|c|}{ BC_03 } & \multicolumn{2}{|c|}{ BC_98 } & \multicolumn{2}{|c|}{ MB_03 } & \multicolumn{2}{|c|}{ MB_98 } \\
\hline & \# stools & Re. $(\%)$ & \# stools & Re. $(\%)$ & \# stools & Re. $(\%)$ & \# stools & Re. $(\%)$ \\
\hline Arbutus unedo & 41 & 92.7 & 18 & 44.4 & 31 & 77.5 & 35 & 25.7 \\
\hline Castanea sativa & 100 & 49 & 72 & 9.7 & 13 & 27.7 & - & - \\
\hline Erica arborea & 82 & 72 & 114 & 77.2 & 13 & 34.2 & 12 & 58.3 \\
\hline Fraxinus ornus & 74 & 68.9 & 1 & 0 & 87 & 55.4 & 7 & 0 \\
\hline Quercus ilex & - & - & 3 & 100 & 33 & 75 & 6 & 0 \\
\hline Quercus pubescens & - & - & 5 & 60 & 17 & 65.4 & 14 & 7.1 \\
\hline
\end{tabular}

Tab. 3 - Structural diversity in the tree layer through distance-independent variables. Measures were computed for living trees with Brillouin and Vertical Eveness (VE) indices, while tree height diversity (THD) index and tree diameter diversity (TDD) index were calculated for both living stems and snags. ( $\mathrm{BC}$ nb): not burned broadleaved-coniferous forest stand; (BC_03): broadleaved-coniferous forest stand burned in 2003; (BC_98): broadleaved-coniferous forest stand burned in 1998; (MB_nb): not burned mixed-broadleaved forest stand; (MB_03): mixed-broadleaved forest stand burned in 2003; (MB_98): mixed-broadleaved forest stand burned in 1998 .

\begin{tabular}{lcccccc}
\hline Structural diversity & BC_nb & BC__03 & BC_98 & MB_nb & MB_03 & MB_98 \\
\hline Richness (n taxa) & 10 & 5 & 9 & 7 & 8 & 8 \\
Brillouin diversity (HB) & 1.617 & 1.077 & 1.273 & 1.55 & 1.489 & 1.402 \\
Brillouin evenness (E) & 0.717 & 0.749 & 0.616 & 0.81 & 0.781 & 0.707 \\
THD living stems & 1.469 & 1.838 & 0.795 & 1.28 & 1.887 & 1.026 \\
THD snags & 1.516 & 1.487 & 1.122 & 0.966 & 1.716 & 0.668 \\
TDD living stems & 1.02 & 1.736 & 0.296 & 0.731 & 1.713 & 0.628 \\
TDD snags & 1.314 & 1.063 & 1.009 & 0.8 & 1.119 & 0.367 \\
VE & 0.86 & 0.82 & 0.97 & 0.81 & 0.8 & 0.88 \\
\hline
\end{tabular}


Tab. 4 - Ripley's $K(t)$ for living stems, snags and total stems in the six plots. Clumped distribution is indicated by " $\circ$ ", while "-." indicates no statistically significant difference from the CSR (Complete Spatial Randomness) hypothesis ( $<0.01)$. Dark symbols ("•") stands for the $K(t)$ statistics being consistent with the $O(r)$. (BC_nb): not burned broadleaved-coniferous forest stand; (BC_03): broadleaved-coniferous forest stand burned in 2003; BC 98: broadleaved-coniferous forest stand burned in 1998; (MB nb): not burned mixed-broadleaved forest stand; (MB_03): mixed-broadleaved forest stand burned in 2003; MB_98: mixed-broadleaved forest stand burned in 1998.

\begin{tabular}{|c|c|c|c|c|c|c|c|c|c|c|c|c|c|c|c|c|c|c|c|c|c|c|c|c|c|c|}
\hline \multirow{2}{*}{ Plot } & \multirow{2}{*}{ Classes } & \multicolumn{25}{|c|}{ Distance (m) } \\
\hline & & 1 & 2 & 3 & 4 & 5 & 6 & 7 & 8 & 9 & 10 & 11 & 12 & 13 & 14 & 15 & 16 & 17 & 18 & 19 & 20 & 21 & 22 & 23 & 24 & 25 \\
\hline \multirow[t]{3}{*}{$\mathrm{BC}_{-} \mathrm{nb}$} & Living stems & $\bullet$ & $\bullet$ & $\bullet$ & $\bullet$ & $\bullet$ & $\bullet$ & $\bullet$ & $\bullet$ & $\bullet$ & $\bullet$ & $\bullet$ & $\bullet$ & O & 0 & O & O & o & O & O & O & O & O & O & o & 0 \\
\hline & Snags & $\bullet$ & $\bullet$ & $\bullet$ & $\bullet$ & $\bullet$ & $\bullet$ & $\bullet$ & $\bullet$ & $\bullet$ & $\bullet$ & $\bullet$ & $\bullet$ & $\bullet$ & $\bullet$ & $\bullet$ & $\bullet$ & $\bullet$ & $\bullet$ & O & O & $\bullet$ & $\bullet$ & $\bullet$ & O & $\bullet$ \\
\hline & Total Stems & $\bullet$ & $\bullet$ & $\bullet$ & $\bullet$ & $\bullet$ & $\bullet$ & $\bullet$ & $\bullet$ & $\bullet$ & $\bullet$ & $\bullet$ & $\bullet$ & $\bullet$ & $\bullet$ & $\bullet$ & $\bullet$ & 0 & O & o & o & O & $\bullet$ & ० & O & o \\
\hline \multirow[t]{3}{*}{$\mathrm{BC} \_03$} & Living stems & - & - & - & - & $\bullet$ & 0 & o & o & o & o & o & - & - & - & - & o & - & - & - & - & $\bullet$ & o & o & $\bullet$ & o \\
\hline & Snags & - & - & $\bullet$ & $\bullet$ & $\bullet$ & $\bullet$ & $\bullet$ & $\bullet$ & $\bullet$ & $\bullet$ & o & $\bullet$ & $\bullet$ & O & O & O & O & O & ○ & O & O & O & O & ○ & o \\
\hline & Total Stems & - & - & $\bullet$ & $\bullet$ & $\bullet$ & $\bullet$ & $\bullet$ & $\bullet$ & $\bullet$ & $\bullet$ & o & $\bullet$ & $\bullet$ & $\bullet$ & $\bullet$ & $\bullet$ & O & $\bullet$ & o & ○ & $\bullet$ & O & $\bullet$ & $\bullet$ & $\bullet$ \\
\hline \multirow[t]{3}{*}{ BC_98 } & Living stems & - & $\bullet$ & 0 & $\bullet$ & $\bullet$ & $\bullet$ & $\bullet$ & o & $\bullet$ & o & $\bullet$ & $\bullet$ & o & o & o & o & o & $\bullet$ & o & 0 & o & o & 0 & 0 & 0 \\
\hline & Snags & - & $\bullet$ & $\bullet$ & $\bullet$ & $\bullet$ & $\bullet$ & $\bullet$ & $\bullet$ & $\bullet$ & $\bullet$ & $\bullet$ & $\bullet$ & $\bullet$ & $\bullet$ & $\bullet$ & $\bullet$ & $\bullet$ & $\bullet$ & $\bullet$ & $\bullet$ & $\bullet$ & $\bullet$ & O & O & $\circ$ \\
\hline & Total Stems & - & $\bullet$ & $\bullet$ & ○ & $\bullet$ & $\bullet$ & $\bullet$ & $\bullet$ & $\bullet$ & $\bullet$ & $\bullet$ & $\bullet$ & $\bullet$ & $\bullet$ & $\bullet$ & $\bullet$ & $\bullet$ & O & $\bullet$ & $\bullet$ & ○ & $\bullet$ & $\bullet$ & $\bullet$ & ○ \\
\hline \multirow[t]{3}{*}{ MB_nb } & Living stems & - & $\bullet$ & $\bullet$ & $\bullet$ & $\bullet$ & $\bullet$ & $\bullet$ & $\bullet$ & ० & ० & $\bullet$ & ० & $\bullet$ & $\bullet$ & O & o & o & O & ० & ० & O & 0 & - & - & - \\
\hline & Snags & - & - & - & - & - & - & - & - & - & - & - & - & - & - & - & - & - & - & - & - & - & - & - & - & - \\
\hline & Total Stems & - & $\bullet$ & $\bullet$ & $\bullet$ & $\bullet$ & $\bullet$ & $\bullet$ & $\bullet$ & $\bullet$ & $\bullet$ & $\bullet$ & 0 & 0 & O & ○ & 0 & 0 & O & O & 0 & ○ & O & 0 & 0 & - \\
\hline \multirow[t]{3}{*}{ MB_03 } & Living stems & $\bullet$ & $\bullet$ & $\bullet$ & $\bullet$ & $\bullet$ & $\bullet$ & $\bullet$ & $\bullet$ & $\bullet$ & $\bullet$ & $\bullet$ & $\bullet$ & $\bullet$ & $\bullet$ & O & o & o & O & o & 0 & O & 0 & o & O & o \\
\hline & Snags & - & $\bullet$ & $\bullet$ & $\bullet$ & $\bullet$ & $\bullet$ & $\bullet$ & O & $\bullet$ & o & $\bullet$ & O & o & $\bullet$ & 0 & $\bullet$ & $\bullet$ & O & O & ० & O & O & O & o & - \\
\hline & Total Stems & - & $\bullet$ & $\bullet$ & $\bullet$ & $\bullet$ & $\bullet$ & $\bullet$ & $\bullet$ & $\bullet$ & $\bullet$ & $\bullet$ & 0 & ○ & 0 & ○ & O & O & ○ & O & O & ○ & ○ & - & - & - \\
\hline \multirow[t]{3}{*}{ MB_98 } & Living stems & $\bullet$ & $\bullet$ & $\bullet$ & $\bullet$ & $\bullet$ & $\bullet$ & $\bullet$ & $\bullet$ & $\bullet$ & $\bullet$ & $\bullet$ & $\bullet$ & O & O & ० & O & O & O & O & o & O & $\bullet$ & O & O & $\bullet$ \\
\hline & Snags & - & - & - & - & - & - & - & - & - & ○ & ○ & O & - & - & - & - & - & - & - & - & - & - & - & - & - \\
\hline & Total Stems & $\bullet$ & $\bullet$ & $\bullet$ & $\bullet$ & $\bullet$ & $\bullet$ & $\bullet$ & $\bullet$ & $\bullet$ & ○ & $\bullet$ & O & $\bullet$ & $\bullet$ & O & O & O & O & O & ○ & O & O & O & O & ० \\
\hline
\end{tabular}
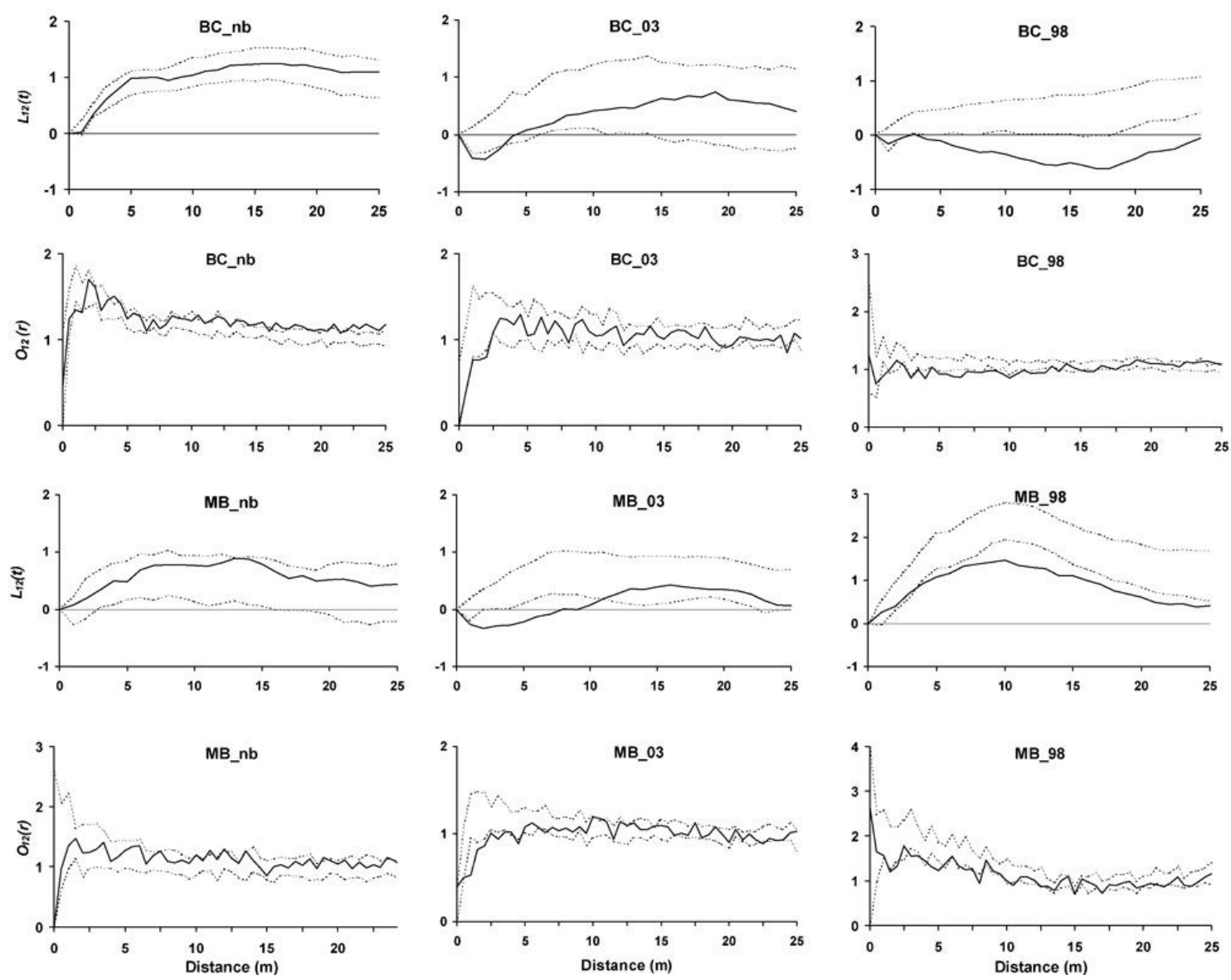

Fig. 2 - Second order bivariate Ripley's $L_{12}(t)$ and O-ring $O_{12}(r)$ analyses for living $v s$. dead stems inside the plots. Solid line is respectively $L_{12}(t)$ and $O_{12}(r)$, while dashed lines represent the $99 \%$ confidence envelopes under the random labelling null model. Points over the con-

fidence envelope show positive spatial interactions (attraction), points below the confidence envelope show negative spatial interaction (repulsion), while points located inside the envelope show no significant spatial interaction. 
centage in BC_03 $\left(\chi^{2}\right.$ test; $\left.p<0.05\right)$.

Higher species diversity values $(H B)$ in the tree layer were found in both unburned plots (Tab. 3). The lowest diversity value was recorded in BC 03, while the index showed a higher value in $\mathrm{BC}$-98. Within the $\mathrm{MB}$ plots the Brillouin index shows a decrease along the chronosequence. Lower evenness values $(E)$ were obtained within both plots burned in 1998. BC 03 showed instead an $E$ value higher than $\overline{\mathrm{BC}} \mathrm{nb}$. The opposite situation was found between MB_03 and MB_nb.

Living stems of both categories had similar THD and TDD patterns: early after fire occurrence higher values of the indices were encountered (Tab. 3). A sharp decrease was evident in the plots burned in 1998, which on the contrary showed the highest VE values. Snag THD and TDD values highlight a different behavior in $\mathrm{BC}$ and $\mathrm{MB}$ plots.

Ripley's $K(t)$ for living trees revealed a clumped distribution in all the plots (Tab. 4). The tendency toward aggregation was confirmed at short distances by the $O$-ring analysis. Only BC 03 showed a slightly reduced aggregation. Standing dead trees were clumped in $\mathrm{BC}$ plots, while in MB plots there was a gradient from a random distribution in MB nb to aggregation in MB 03, with MB_98 showing an intermediate situation. The living vs. dead trees analysis revealed similar tendencies among plots burned in the same wildfire, and differences within the same forest category (Fig. 2). Repulsion was found from $3 \mathrm{~m}$ on in $\mathrm{MB} 98$ and $\mathrm{BC} 98$, while in the more recently burned plots the negative interaction was evident up to $4 \mathrm{~m}$ (BC 03) and $11 \mathrm{~m}$ (MB 03). No significant spatial interactions were found in unburned plots. All the results are consistent with the $O$-ring analyses (Fig. 2).

\section{Discussion}

Fire caused a change in the population structure of both forest categories. The two communities were similar in terms of number and size of fire-killed and surviving tree stems. Fire affected mostly the smaller diameters, greatly reducing their number. At the same time, the majority of largest individuals, mainly maritime pines, were killed.

Following disturbance, the density of living stems and snags showed an opposite behaviour as a consequence of self-restoration strategies and fall dynamics. The processes of tree mortality and snag recruitment are balanced by snag decay and fall (Everett et al. 1999). Snag fall rates vary according to snag size, tree species, the microenvironment, cause and season of mortality. Snag longevity is a site-specific process that needs to be determined for each area of interest (Keen 1929, Everett et al. 1999). Smaller trees are more vulnerable to fire-induced death and usually tend to fall faster than larger diameter snags (Everett et al. 1999,
Chambers \& Mast 2005). In the 1998 plots all snags belonged to the greatest sizeclasses.

The passage of a high intensity fire front induced a modification in the proportion of sprouters and seeders, due to the concurrent presence of species with varying degrees of resistance and resilience to fire. Regeneration strategies can directly influence species abundance and consequently both dominance and evenness values. Consistently with Lloret et al. (2005), the higher presence of resprouters in the mixed-broadleaved forest category determined stability in species richness, even in early successional stages. Highly resilient resprouters can assure species persistence thanks to their ability to produce new shoots immediately after the disturbance event (Keeley 1986, Trabaud 1987b).

Both forest categories showed a generalized increase in structural complexity of living stems immediately following the fire, while in the early post-fire years a decline was registered, reaching values lower that those found for unburned plots. By affecting mostly smaller size stems, fire reduced their pre-disturbance structural dominance. As a consequence, there were more even diameter and height distributions, leading to an increase in structural diversity. This was however a short-lived modification: six years after the perturbation, the high proportional abundance of sprout-origin individuals determined a renewed simplification in structural diversity

Dissimilar patterns of mortality before the disturbance generated a different behavior in the structural diversity of dead stems. In the $\mathrm{BC}$ category, characterized by a high presence of chestnut and maritime pine affected respectively by Chryphonectria parasitica (Murr.) Barr. and Matsucoccus feytaudi Ducasse, stem mortality was rather high and distributed among the different diameter classes also in the unburned plot. On the contrary, in the MB category, no particular factor seems to have a role in determining tree mortality, except the usual competition dynamics.

Fire determined a larger heterogeneity of the vertical structure in the earlier burned plots, enhancing the evenness of cover distribution between the different layers throught the recovery dynamics. The fire event induced an increase in aggregation within the stands. Disturbance by fire has actually been found to increase the degree of clumping (Rebertus et al. 1989, Davis et al. 2005). Fire frequncis or intensities may differently affect patterns of aggregation (Davis et al. 2005). Tree mortality was clumped in all the burned sites, but mortality was also spatially aggregated in $\mathrm{BC} \mathrm{nb}$, confirming that some allogenic mortality agents were acting in the stand.
Segregation mechanisms were generated by the fire, inducing a spatial repulsion between surviving and killed stems. Six years after the fire event, natural restoration dynamics and snag fall processes altered living and dead stems spatial relationships. Close to snags, positive afterlife effects (Kane et al. 2011) such as regeneration establishment and broadleaves resprouting mitigate repulsion.

Fire frequently creates a high degree of spatial variability in plant survival, which partially depends on the size of individuals (Johnson 1992, Huston 1994), fire-resistance mechanisms and flammability of species (McKenzie et al. 1996). Maritime pines were severely damaged by fire, influencing the spatial distribution of both dead and living stems. $P$. pinaster is actually a highly pyrophytic species (Velez 2000), with a high resin content, possibly favoring ignition (Van Wagner 1977) and increasing the amount of energy released when the foliage burns.

Fire severity influences the number and the type of plants dying in a fire and their consequent spatial patterns. Fires of low or medium severity produce a highly selective mortality, depending on the species and size of each individual, while fires of high severity usually kill all individuals, regardless of species or size (Turner et al. 1994). In the latter situation, plant survival is often confined in scattered safe sites (cool spots), resulting in clumps of surviving stems.

Fire severity also influences post-fire regeneration in the burned area (Agee 1993), which is also strongly dependent on the regenerative strategies of species (Pausas 1999b).

Seedling recruitment was similar in richness and abundance within both forest categories immediately after fire. In early successional stages after fire, an abundant establishment of saplings and sprouts has been documented by several authors (e.g., Fulé \& Covington 1994), mostly as a consequence of the reduced competition for resources. However, in sprouter-dominated communities, seeders are often unfavoured (Naveh 1975, Trabaud 1987a). The dense shrub layer originated by the strong resprouting six years after the fire event in MB_98 probably hampered seedling survival, as confirmed by the very scarce seedling number. BC 98 has instead a very high seedling density, the majority of them being $P$. pinaster individuals. As found in other studies (e.g., Moravec 1990), five years after fire there is usually a high rate of pine establishment. Mortality of maritime pine seedlings is essentially affected by interspecific competition (Fernandes \& Rigolot 2007), particularly with shrub species, whose detrimental effects on genus Pinus have been often described (De las Heras et al. 2002, Quevedo et al. 2007). Moreover, seeder species persistence could 
be endangered by the alteration of fire regimes, leading to differnces according to theit range of tolerance (Verdú et al. 2007). Severe crown fires can negatively affect post-disturbance regeneration, causing higher damages, and reducing seed dispersal, viability and emergence rate (Fernandes \& Rigolot 2007).

Fire effects were found to affect more tree dimensions and spatial patterns rather than composition. Snag dynamics, in particular, were a key element of the observed changes in forest structure, mainly as a consequence of their short-term evolution.

The sprouter-dominated forest stands reveal a major difficulty in restoring the prefire conditions. Since the majority of adult conifers in the whole area were killed by the fire, the low number of pine seedlings can cause a partial failure of direct regeneration (Rodrigo et al. 2004) and affect future forest composition.

The scarce number of tree seedlings six years after fire occurrence, along with the high resprouting rates and ground cover of shrub species, may suggest a shift towards a community dominated by a low structured, shrub vegetation. A similar scenario has been proposed for the Mediterranean basin with higher disturbance frequency (Naveh 1974, Trabaud 1991). An increase in the recurrence of high-intensity fires may alter recovery dynamics of usually resilient pine species as a consequence of shrub invasion, delaying succession processes and inducing a regression in the forest structure (Buscardo et al. 2011).

Forthcoming changes in fire regimes, yet largely unknown (Fulé \& Covington 1998), and the need to study the response of fireprone Mediterranean vegetation over several decades (Capitanio \& Carcaillet 2008), make it necessary to further investigate post-disturbance structural dynamics, also through a long-term monitoring approach (Beghin et al. 2010).

\section{References}

Aakala T, Kuuluvainen T, De Grandpré L, Gauthier S (2007). Trees dying standing in the northeastern boreal old-growth forests of Quebec: spatial patterns, rates, and temporal variation. Canadian Journal of Forest Research 37: 50-61. - doi: 10.1139/x06-201

Agee JK (1993). Fire ecology of pacific northwest forests. Island Press, Washington, DC, USA.

Attiwill PM (1994). The disturbance of forest ecosystems. The ecological basis for conservative management. Forest Ecology and Management 63: 247-300. - doi: 10.1016/0378-1127(94) 90114-7

Beghin R, Lingua E, Garbarino M, Lonati M, Bovio G, Motta R, Marzano R (2010). Pinus sylvestris forest regeneration under different post-fire restoration practices in the northwestern
Italian Alps. Ecological Engineering 36: 13651372. - doi: 10.1016/j.ecoleng.2010.06.014

Blondel J, Aronson J, Bodiou J-Y, Boeuf G (2010). The Mediterranean region. Biological diversity in space and time. Oxford University Press, New York, USA.

Bond WJ, van Wilgen BW (1996). Fire and plants. Chapman \& Hall, London, UK.

Brillouin L (1956). Science and information theory. Academic Press, New York, USA.

Capitanio R, Carcaillet C (2008). Post-fire Mediterranean vegetation dynamics and diversity: a discussion of succession models. Forest Ecology and Management 255: 431-439. - doi: 10.1016/ j.foreco.2007.09.010

Buscardo E, Freitas H, Pereira JS, De Angelis P (2011). Common environmental factors explain both ectomycorrhizal species diversity and pine regeneration variability in a post-fire Mediterranean forest. Mycorrhiza 21: 549-558. - doi: 10.1007/s00572-011-0363-5

Carvalho A, Flannigan M, Logan K, Miranda A, Borrego C (2008). Fire activity in Portugal and its relationship to weather and the Canadian fire weather index system. International Journal of Wildland Fire 17: 328-338. - doi: 10.1071/ WF07014

Chambers CL, Mast JN (2005). Ponderosa pine snag dynamics and cavity excavation following wildfire in northern Arizona. Forest Ecology and Management 216: 227-240. - doi: 10.1016/j.foreco.2005.05.033

Davis MA, Curran C, Tietmeyer A, Miller A (2005). Dynamic tree aggregation patterns in a species-poor temperate woodland disturbed by fire. Journal of Vegetation Science 16: 167-174. - doi: 10.1111/j.1654-1103.2005.tb02352.x

De las Heras J, Martínez-Sánchez JJ, GonzálezOchoa AI, Ferrandis P, Herranz JM (2002). Establishment of Pinus halepensis Mill. saplings following fire: effects of competition with shrub species. Acta Oecologica 23: 91-97. - doi: 10.1016/S1146-609X(02)01138-4

Dury M, Hambuckers A, Warnant P, Henrot A, Favre E, Ouberdous M, François L (2011). Responses of European forest ecosystems to $21^{\text {st }}$ century climate: assessing changes in interannual variability and fire intensity. I-Forest 4: 82-99 doi: 10.3832/ifor0572-004

Everett R, Lehmkuhl J, Schellhaas R, Ohlson P, Keenum D, Riesterer H, Spurbeck D (1999). Snag dynamics in a chronosequence of 26 wildfires on the east slope of the cascade range in Washington State, USA. International Journal of Wildland Fire 9: 223-234. - doi: 10.1071/ WF00011

Fernandes PM, Rigolot E (2007). The fire ecology and management of maritime pine (Pinus pinaster Ait.). Forest Ecology and Management 241: 1-13. - doi: 10.1016/j.foreco.2007.01.010

Fulé PZ, Covington WW (1994). Fire regime disruption and pine-oak forest structure in the Sierra Madre Occidental, Durango, Mexico. Restoration Ecology 2: 261-272. - doi: 10.1111/j. 1526100X.1994.tb00058.x

Fulé PZ, Covington WW (1998). Spatial patterns of Mexican pine-oak forests under different recent fire regimes. Plant Ecology 134: 197-209. doi: 10.1023/A:1009789018557

Getis A, Franklin J (1987). Second-order neighborhood analysis of mapped point patterns. Ecology 68: 473-477. - doi: 10.2307/1938452

Gillson L (2009). Landscapes in time and space. Landscape Ecology 24: 149-155. - doi: 10.1007/ s10980-008-9315-7

González JR, Pukkala T (2007). Characterization of forest fires in Catalonia (north-east Spain). European Journal of Forest Research 126: 421429. - doi: 10.1007/s10342-006-0164-0

Good P, Moriondo M, Giannakopoulos C, Bindi $M$ (2008). The meteorological conditions associated with extreme fire risk in Italy and Greece: relevance to climate model studies. International Journal of Wildland Fire 17:155-165. - doi: 10.1071/WF07001

Goreaud F, Pélissier R (2003). Avoiding misinterpretation of biotic interactions with the intertype $K_{12}$-function: population independence $v s$. random labelling hypothesis. Journal of Vegetation Science 14: 681-692. - doi: 10.1111/j.16541103.2003.tb02200.x

Haase P (1995). Spatial pattern analysis in ecology based on Ripley's $K$-function: introduction and methods of edge correction. Journal of Vegetation Science 6: 575-582. - doi: 10.2307/ 3236356

Haase P (2001). Can isotropy vs. anisotropy in the spatial association of plant species reveal physical vs. biotic facilitation? Journal of Vegetation Science 12: 127-136. - doi: 10.1111/j.16541103.2001.tb02623.x

Hanes TL (1971). Succession after fire in the chaparral of southern California. Ecological Monographs 41: 27-52. - doi: 10.2307/1942434

Hodgkinson KC (1998). Sprouting success of shrubs after fire: height-dependent relationships for different strategies. Oecologia 115: 64-72. doi: 10.1007/s004420050492

Huston MA (1994). Biological diversity: the coexistence of species on changing landscapes. Cambridge University Press, Cambridge, UK.

Johnson EA (1992). Fire and vegetation dynamics: studies from the North American boreal forest. Cambridge University Press, New York, USA.

Kane JM, Meinhardt KA, Chang T, Cardall BL, Michalet R, Whitham TG (2011). Drought-induced mortality of a foundation species (Juniperus monosperma) promote positive afterlife effects in understory vegetation. Plant Ecology 212:733-741. - doi: 10.1007/s11258-010-9859-x Keeley JE (1986). Resilience of mediterranean shrub communities to fires. In: "Resilience in mediterranean-type ecosystems" (Dell B, Hopkins AJM, Lamont BB eds). W Junk, Dordrecht, The Netherlands, pp. 95-112.

Keen FP (1929). How soon do yellow pine snags fall? Journal of Forestry 27: 735-737.

Kenkel NC (1988). Pattern of self-thinning in jack pine: testing the random mortality hypothesis. Ecology 69: 1017-1024. - doi: 10.2307/1941257 Kuuluvainen T, Järvinen E, Hokkanen TJ, Rou- 
vinen S, Heikkinen K (1998). Structural heterogeneity and spatial autocorrelation in a natural mature Pinus sylvestris dominated forest. Ecography 21: 159-174. - doi: 10.1111/j.1600-0587. 1998.tb00670.x

Kuuluvainen T, Leinonen K, Nygren M, Penttinen A (1996). Statistical opportunities for comparing stand structural heterogeneity in managed and primeval forests: an example from boreal spruce forest in southern Finland. Silva Fennica 30: 315-328. [online] URL: https://helda.helsinki.fi/ bitstream/handle/1975/9243/030-2-

3_Kuuluvainen.pdf? sequence $=3$

Lavorel S, Canadell J, Rambal S, Terradas J (1998). Mediterranean terrestrial ecosystems: research priorities on global change effects. Global Ecology and Biogeography Letters 7: 157-166. doi: $10.2307 / 2997371$

Lavorel S (1999). Ecological diversity and resilience of mediterranean vegetation to disturbance. Diversity and Distributions 5: 3-13. - doi: 10.1046/j.1472-4642.1999.00033.x

Le Houérou HN (1987). Vegetation wildfires in the Mediterranean basin: evolution and trends. Ecologia Mediterranea 13: 13-24.

Lloret F, Estevan H, Vayreda J, Terradas J (2005). Fire regenerative syndromes of forest woody species across fire and climatic gradients. Oecologia 146: 461-468. - doi: 10.1007/s00442-005-0206-

Lloret F, Marí G (2001). A comparison of medioeval and the current fire regimes in managed pine forests of Catalonia (NE Spain). Forest Ecology and Management 141: 155-163. - doi: 10.1016/S0378-1127(00)00323-6

Lloret F, Pausas JG, Vilà M (2003). Responses of Mediterranean plant species to different fire frequencies in Garraf Natural Park (Catalonia, Spain): Field observations and modelling predictions. Plant Ecology 167: 223-235. - doi: 10.1023/A:1023911031155

Lloret F, Peñuelas J, Estiarte M (2004). Experimental evidence of reduced diversity of seedlings due to climate modification in a Mediterranean-type community. Global Change Biology 10: 248-258. - doi: 10.1111/j.1365-2486.2004 00725.x

Lloret F, Peñuelas J, Prieto P, Llorens L, Estiarte M (2009). Plant community changes induced by experimental climate change: seedling and adult species composition. Perspectives in Plant Ecology, Evolution and Systematics 11: 53-63. - doi: 10.1016/j.ppees.2008.09.001

Lloret F, Vilà M (2003). Diversity patterns of plant functional types in relation to fire regime and previous land use in Mediterranean woodlands. Journal of Vegetation Science 14: $387-$ 398. - doi: 10.1111/j.1654-1103.2003.tb02164.x Lotwick HW, Silverman B.W (1982). Methods for analysing spatial processes of several types of points. Journal of the Royal Statistical Society B 44: 406-413. [online] URL: http://www.jstor.org stable/2345499

Magurran AE (2004). Measuring biological diversity. Blackwell Science, Oxford, UK.

Marzano R (2006). Assessing biodiversity in a changing fire regime: post- fire dynamics in a Mediterranean area. PhD thesis, Dottorato di Ricerca in Scienze Agrarie, Forestali e Agroalimentari (XVIII ciclo), University of Torino, pp. 204.

McKenzie D, Alvarado E, Peterson DL (1996). Extrapolation problems in modeling fire effects at large spatial scales: A review. International Journal of Wildland Fire 6: 165-176. - doi: 10.1071/WF9960165

Moravec J (1990). Regeneration of NW African Pinus halepensis forests following fire. Vegetatio 87: 29-36. - doi: 10.1007/BF00045652

Moreira F, Ferreira PG, Rego FC, Bunting S (2001). Landscape changes and breeding bird assemblages in northwestern Portugal: the role of fire. Landscape Ecology 16: 175-187. - doi: 10.1023/A:1011169614489

Moreno JM, Oechel WC (1994). The role of fire in Mediterranean type ecosystems. Springer-Verlag, Berlin, Germany.

Mouillot D, Rambal S, Joffre R (2002). Simulating climate change impacts on fire frequency and vegetation dynamics in a Mediterranean-type ecosystem. Global Change Biology 8: 1-15. - doi: 10.1046/j.1365-2486.2002.00494. $\mathrm{x}$

Naveh Z (1974). Effects of fire in the Mediterranean Region. In: "Fire and ecosystems" (Kozlowski TT, Ahlgren CE eds). Academic Press, New York, USA, pp. 401-434.

Naveh Z (1975). The evolutionary significance of fire in the Mediterranean region. Vegetatio 29: 199-208. - doi: 10.1007/BF02390011

Neumann M, Starlinger F (2001). The significance of different indices for stand structure and diversity in forests. Forest Ecology and Management 145: 91-106. - doi: 10.1016/S0378-1127 (00)00577-6

Pausas JG (1999a). The response of plant functional types to changes in the fire regime in Mediterranean ecosystems. A simulation approach. Journal of Vegetation Science 10: 717723. - doi: $10.2307 / 3237086$

Pausas JG (1999b). Mediterranean vegetation dynamics: modelling problems and functional types. Plant Ecology 140: 27-39. - doi: 10.1023/ A:1009752403216

Pausas JG, Fernández-Muñoz S (2012). Fire regime changes in the Western Mediterranean Basin: from fuel-limited to drought-driven fire regime. Climatic Change 110 (1-2): 215-226. doi: 10.1007/s10584-011-0060-6

Peñuelas J, Filella I (2001). Phenology: responses to a warming world. Science 294 (5543): 793 795. - doi: $10.1126 /$ science. 1066860

Peñuelas J, Filella I, Comas P (2002). Changed plant and animal life cycles from 1952 to 2000 in the Mediterranean region. Global Change Biology 8: 531-544. - doi: 10.1046/j.1365-2486. 2002.00489.x

Piñol J, Terradas J, Lloret F (1998). Climate warming, wildfire hazard, and wildfire occurrence in coastal eastern Spain. Climatic Change 38: 345-357. - doi: 10.1023/A:1005316632105

Quevedo L, Rodrigo A, Espelta JM (2007). Post- fire resprouting ability of 15 non-dominant shrub and tree species in Mediterranean areas of NE Spain. Annals of Forest Sciences 64: 883-890. doi: 10.1051/forest:2007070

Rebertus AJ, Williamson GB, Moser EB (1989). Fire-induced changes in Quercus laevis spatial pattern in Florida sandhills. Journal of Ecology 77: 638-650. - doi: 10.2307/2260975

Ripley BD (1977). Modelling spatial patterns (with discussion). Journal of the Royal Statistical Society B 39: 172-212. [online] URL: http://www.jstor.org/stable/2984796

Rodrigo A, Retana J, Picò FX (2004). Direct regeneration is not the only response of Mediterranean forest to large fires. Ecology 85: 716-729. - doi: 10.1890/02-0492

Rouvinen S, Kuuluvainen T (2005). Tree diameter distributions in natural and managed old Pinus sylvestris-dominated forests. Forest Ecology and Management 208: 45-61. - doi: 10.1016/j.foreco. 2004.11.021

Scarascia-Mugnozza G, Oswald H, Piussi P, Radoglou K (2000). Forests of the Mediterranean region: gaps in knowledge and research needs. Forest Ecology and Management 132: 97-109. doi: 10.1016/S0378-1127(00)00383-2

Trabaud L (1987a). The role of fire in ecological systems. SPB Academic Publishers, The Hague, The Netherlands.

Trabaud L (1987b). Natural and prescribed fire: survival strategies of plants and equilibrium in Mediterranean ecosystems. In: "Plant response to stress. Functional analysis in Mediterranean ecosystems" (Tenhunen JD, Catarino FM, Lange OL, Oechel WC eds), Springer, Berlin, Germany, pp. 607-621.

Trabaud L (1991). Fire regimes and phytomass growth dynamics in a Quercus coccifera garrigue. Journal of Vegetation Science 2: 307-314. - doi: 10.2307/3235921

Trabaud L (1994). Postfire plant community dynamics in the Mediterranean Basin. In: "The role of fire in Mediterranean-type Ecosystems" (Moreno JM, Oechel WC eds). Ecological Studies, vol. 107, Springer, New York, USA, pp. 115.

Turner MG, Hargrove WW, Gardner RH, Romme WH (1994). Effects of fire on landscape heterogeneity in Yellowstone National Park, Wyoming. Journal of Vegetation Science 5 (5): 731-742. doi: $10.2307 / 3235886$

Van Wagner CE (1977). Conditions for the start and spread of crown fire. Canadian Journal of Forest Research 7: 23-34. - doi: 10.1139/x77004

Vázquez A, Moreno JM (2001). Spatial distribution of forest fires in Sierra de Gredos (Central Spain). Forest Ecology and Management 147: 55-65. - doi: 10.1016/S0378-1127(00)00436-9

Vega JA, Fernández C, Pérez-Gorostiaga P, Fonturbel T (2010). Response of maritime pine (Pinus pinaster Ait.) recruitment to fire severity and post-fire management in a coastal burned area in Galicia (NW Spain). Plant ecology 206: 297-308. - doi: 10.1007/s11258-009-9643-y Velez R (2000). La defensa contra incendios fore- 
stales. Fundamentos y experiencias (forest fire prevention. Principles and experiences). McGraw-Hill, Madrid, Spain.

Verdú M, Pausas JG, Segarra-Moragues JG, Ojeda F (2007). Burning phylogenies: fire, molecular evolutionary rates, and diversification Evolution 61(9): 2195-2204. - doi: 10.1111/j. 1558-5646.2007.00187.x

Whelan RJ (1995). The ecology of fire. Cambridge University Press, Cambridge, UK.

Wiegand T, Moloney KA (2004). Rings, circles, and null-models for point pattern analysis in ecology. Oikos 104: 209-229. - doi: 10.1111/j.00301299.2004.12497.x

Wiegand T, Moloney KA, Milton SJ (1998). Population dynamics, disturbance, and pattern evolution: identifying the fundamental scales of organization in a model ecosystem. The American Naturalist 152: 321-337. - doi: 10.1086/ 286172

Zedler PH, Gautier CR, McMaster GS (1983). Vegetation change in response to extreme events: the effect of a short interval between fires in California chaparral and coastal scrub. Ecology 64: 809-818. - doi: 10.2307/1937204

\section{Supplementary Material}

Appendix 1 - Diversity indices and the corresponding equations.

Link: Marzano_612@suppl001.pdf 